Meta

Journal des traducteurs

Translators' Journal

\title{
A Peculiar Burden: Some Technical Problems of Translating Opera for Performance in English
}

\section{Ronnie Apter}

Volume 30, numéro 4, décembre 1985

URI : https://id.erudit.org/iderudit/001899ar

DOI : https://doi.org/10.7202/001899ar

Aller au sommaire du numéro

Éditeur(s)

Les Presses de l'Université de Montréal

ISSN

0026-0452 (imprimé)

1492-1421 (numérique)

Découvrir la revue

Citer cet article

Apter, R. (1985). A Peculiar Burden: Some Technical Problems of Translating

Opera for Performance in English. Meta, 30(4), 309-319.

https://doi.org/10.7202/001899ar 


\section{A PECULIAR BURDEN : SOME TECHNICAL PROBLEMS OF TRANSLATING OPERA FOR PERFORMANCE IN ENGLISH}

RONNIE APTER

Translating an opera into performable English presents all the problems of prosody posed by translating a verse drama, plus a number of problems peculiar to itself. The translator of dramatic verse may choose to imitate the verse form of his original, but he is not a priori constrained to translate syllable for syllable, stress for stress, and burden for burden. The opera translator largely is. The opera translator must not only find the right meaning ; he must place the right meaning on the right note. Moreover, he must take into account the constraints on word choice imposed by the vocal apparatus itself. At least music returns to the translator what it takes away : vocal color may impart drama to a rather ordinary word. When words and music fit, and properly reinforce each other, the laboring translator is well rewarded.

Since most operas performed today date from the nineteenth century, their librettos are usually written in a variety of rhymed, metrical stanzas. The composers set these stanzas to musical phrases and sections which sometimes emphasize the verbal format, sometimes downplay it, and sometimes (but rarely) distort it. Thus, two separate aural systems, the musical and the verbal, pattern sense in an opera. Mark Herman and I usually translate rhymed librettos into rhymed English. However, we try to let the spirit, not the letter, of the relationship between the two aural systems dictate our stanza form. If a stanza rhymed $a b a b$ closes properly if rhymed $a b c b$, we see no reason not to change the rhyme. If music emphasizes an $a a b b$ pattern, we stick to couplets. The whole point of stanza form is to group and separate ideas.

In fact, when people find out that we translate opera, they most commonly ask, "Isn't it hard to find all those rhymes ?" Well, no, actually. We find rhyme fairly easy to get, as this excerpt from our translation of Mozart/Schikaneder's The Magic Flute may hear out :

\section{PAPAGENO :}

No, I'm going home to bed,

for as you yourselves have said,

this Sarastro is a beast,

an undoubted evildoer,

an implacable pursuer,

who will spit me on a skewer

for his dogs to have a feast !

(Act I, \#5, meas. 147-159, p. 46.)

Rhyme is only one strategem among many for creating recognizable stanza forms. The translator may use rhyme's cousins - off-rhyme (line-time), weak rhyme (majorsqualor), half rhyme (kitty-pitted), and consonant rhyme (slat-slit) - alone or in com- 
bination with other devices like assonance and alliteration. The following excerpt from our translation of Verdi/Romani's Un giorno di regno illustrates the use of half rhyme and assonance :

THE CHEVALIER :

Ah, my friends, I am transmuted

from the man you knew in Paris,

from the madcap of the barracks,

from a soldier to a statesman, a philosopher and king.

(Act I, \#4, "Compagnoni di Parigi", p. 31.)

"Paris" and "barracks" are half rhymes. The first three lines are tied together by assonance on "am", "transmuted," "man", "Paris", "madcap", and "barracks". The longer final line, devoid of half rhyme or assonance, by its difference signals the close of the stanza and of the musical section.

In his Ring, Wagner alliterates rather than rhymes, forcing the translator to deploy more subtle means for signaling stanza form. Closure, the signaling of the end of a section, becomes more dependent on the music. Consider the following :

\section{FAFNER.}
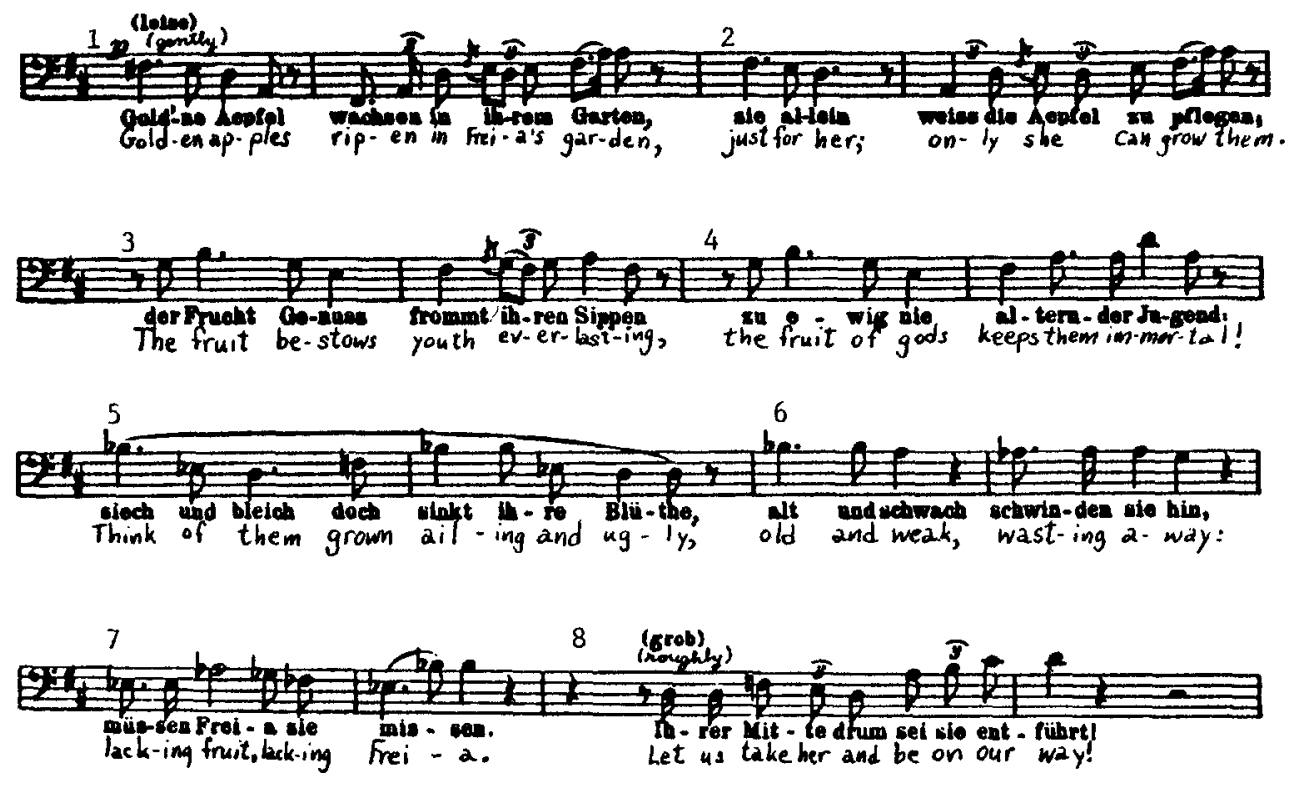

(Das Rheingold, Scene ii, p. 74)

Each of the eight lines of verse numbered above is allotted two bars of music, both in English and German, and each line is separated from its fellows by rests. In the English, lines 1-4 are bound by alliteration on $g$ and $g r$, and also alliteration on $f r$. Lines 5-8 alliterate on vowels (all initial vowels are considered to alliterate) and on $w$, but they pick up the $g r$ and $f r$ to tie into the first four lines. Line 8 closes the stanza for three reasons. First, it and line 6 are the only ones without alliterative reference to the first four lines. 
Second, it and line 6 are the only two with endings on stressed syllables. Third, "way" is the only line-ending word which Wagner sets on a downbeat. Both aural systems must combine for the listener to hear the closure.

So far, I have been discussing how to match verbal to musical rhythm. However, it is possible to set verbal metrics against musical metrics. The effect is much stronger than that caused by enjambment in spoken verse. We use it in Verdi/Piave's $L a$ Traviata . Alfredo sings :

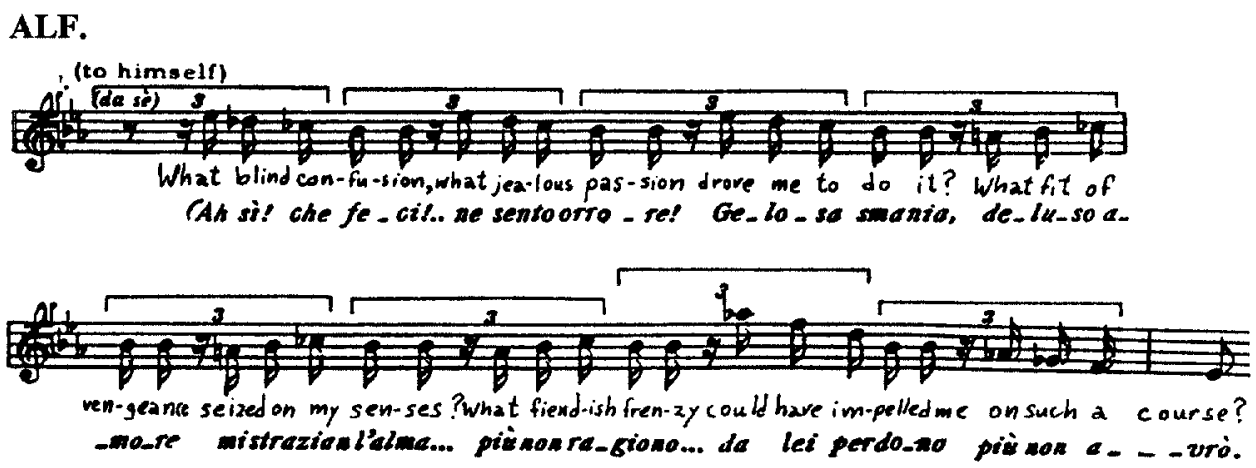

(II.ii, pp. 283-84)

Piave's Italian stanza consists of three ten-syllable lines plus a nine-syllable line, all four lines broken by a caesura after the fifth syllable and rhymed

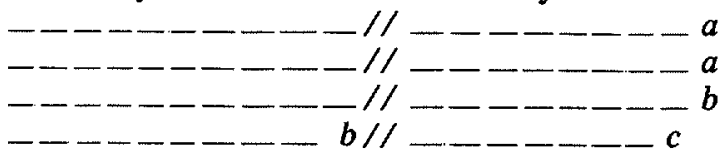

Verdi followed this pattern by placing the second a-rhyme and the c-rhyme on downbeats, dividing the stanza into two units. We, instead, divided the stanza into two fifteen-syllable lines, followed by a nine-syllable line :

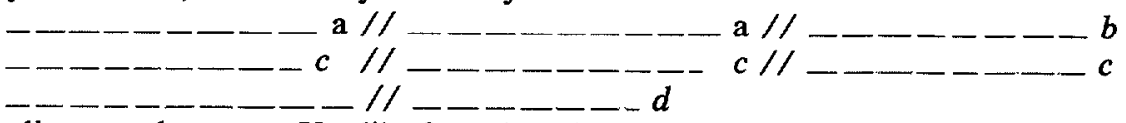

These lines push across Verdi's first downbeat, causing a rhythmic confusion unresolved until the end of the stanza. This confusion, we feel, represents Alfredo's emotional state.

We have moved into the realm of what music and words in combination can do, technically speaking, that words alone cannot. There are other possibilities. For instance, two, three, four, seven, or more people can concurrently sing different lines, while the music makes sense of the verbal hash. Or, music can be used for non-verbal onomatopoeia : a trill on "tremble" trembles. Also, the very mechanics of singing can be used to depict the emotional content of words.

Different lines, when sung concurrently, are very difficult for the listener to grasp. Usually the translator must rely on the music, the acting, and the development of the plot thus far to make meanings clear. Even so, the translator tries to get rhymes and assonances to line up vertically, so that the singers can blend their voices more easily, and to assure the audience that there is some verbal shape. Verdi loved to write such sections, so my example is drawn from his Un giorno di regno. The Chevalier, pretending to 
be a king, has given orders preventing the marriage of his estranged love, the Marquise, to the Count :

CHEVALIER :

MARQUISE :

I have put her on the defensive.

I am trembling, apprehensive.

JULIETTE and ÉDOUARD :

COUNT :

She is trembling, apprehensive,

My displeasure is quite extensive.

BARON and TREASURER :

She is trembling, apprehensive,

But she will thaw.

His inventiveness inspires me with awe.

It is sticking in his craw,

It is sticking in my craw, word is law.
She is trembling with consternation.

Shall I answer his provocation?

and the Count would voice his indignation.

I would voice my indignation.

But a monarch's

Yes, her anger soon will thaw. This is not what I foresaw. but a monarch's word is law. but a monarch's word is law. His word is law.

(Act II, \#24, "A tal colpo," p. 321 et seq.)

The above is a simplified schematic diagram of intricate verbal meshings. Their permutations cover over twenty-three pages of the piano-vocal score. It takes days to cut the phrases apart and fit them with the music, because for slight rhythmic variants Verdi will contract or differently break his Italian phrases at points where the English won't contract or break. It sometimes seems disheartening to spend so much time on words which the audience will never understand. Still, the words help the singers act and the director block. For example, Édouard and Juliette may be by the Marquise when their lines reflect hers, and cross to talk to the Count when their lines reflect his. The Count knows he is indignant ; the Chevalier knows he is gloating. All the same, such ensembles will never be our favorite translating chore.

We have more fun with music's ability to paint words. While the poet is limited to the small stock of onomatopoetic words in English like "buzz," "mumble," and "ding-

\section{BELMONTE}
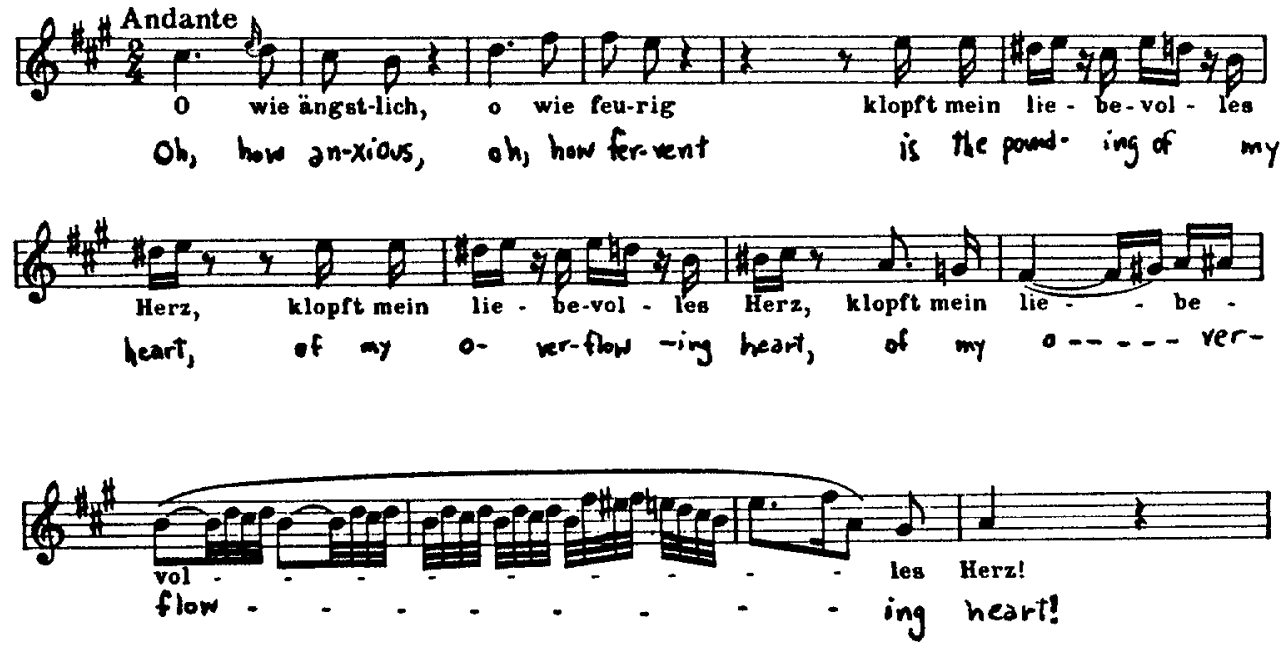

(Act I, \#4, meas. 5-18, p.31) 
dong," music can add onomatopoeia to words which themselves lack it. For instance, in Mozart/Stephanie's The Abduction from the Seraglio, the tenor's heart is so full of love on the word "liebevolles" (love-filled) that it overflows into a cadenza. Hence our translation :

Note that Mozart also suggests the character's emotional state by inserting rests between the syllables of his words. Belmonte is rendered breathless with excitement and love. We were careful to let the rests break up the English words, too.

Knowing that Mozart liked these effects, we add some of our own to The Abduction. We place the word "stuck" on Osmin's low, fermataed E-flat, and then have him repeat it like a stuck record :

\section{OSMIN}

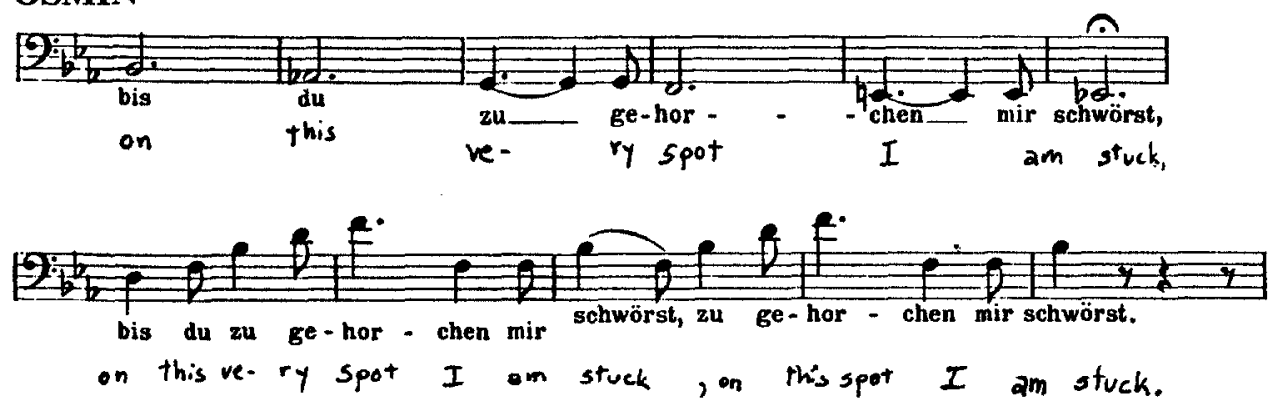

(Act II, \#9, meas. $26-36$, p. 63)

When Blonde sings, "Freud' und Jubel prophezeihn," Mozart peals her vocal line like a liberty bell, so we write :

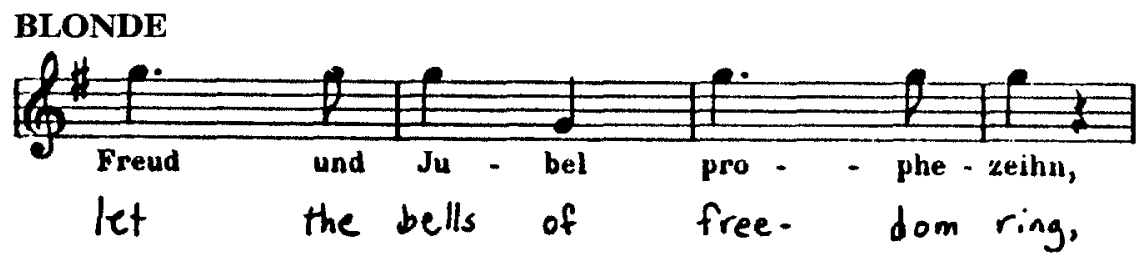

(Act II, \#12, meas. 135-38, p. 94)

Mozart was able to paint emotion by using the physical apparatus of the singer. The Queen of the Night's aria "Der Hölle Rache kocht in meinem Herzen" on a record may sound as if the Queen were laughing happily during the high coloratura, although this is an aria of vengeance. The notes are so high, the tones so pure, that it is hard to connect them with anger : 


\section{THE QUEEN OF THE NIGHT}

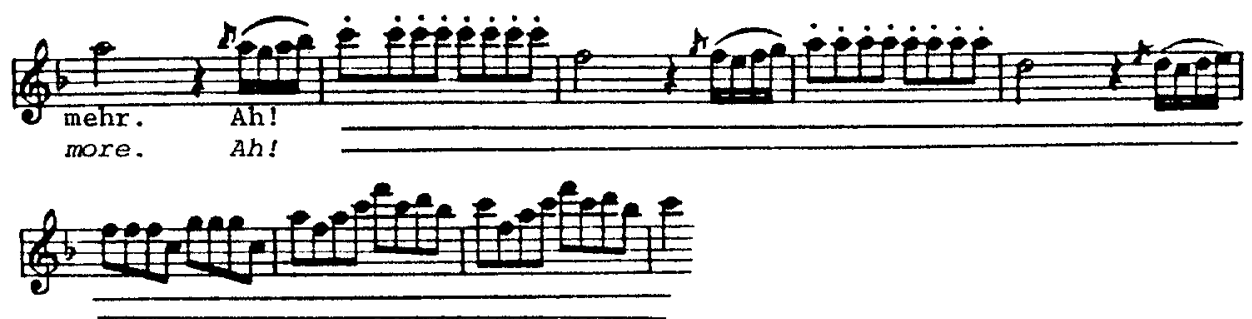

(The Magic Flute, Act II, \#14, meas. 24-32, p. 119)

In Mozart's day, these notes were always sung by a live singer to a live audience, which got to see the soprano contorting her face as if in anger to reach the high notes. A soprano must move her diaphragm rapidly up and down to separate the notes, so her upper body seems to be shaking with rage. The translator gives the Queen an "ah !" and gets out of her way.

The humor of tongue-twisters also seems dependent on the physical effort needed to pronounce them. The audience is amused by so much agility expended to achieve so frivolous a result. Czech, hard enough to pronounce in general, is triple-trouble in tongue-twisters :

VIVACE.

LADISLAV.
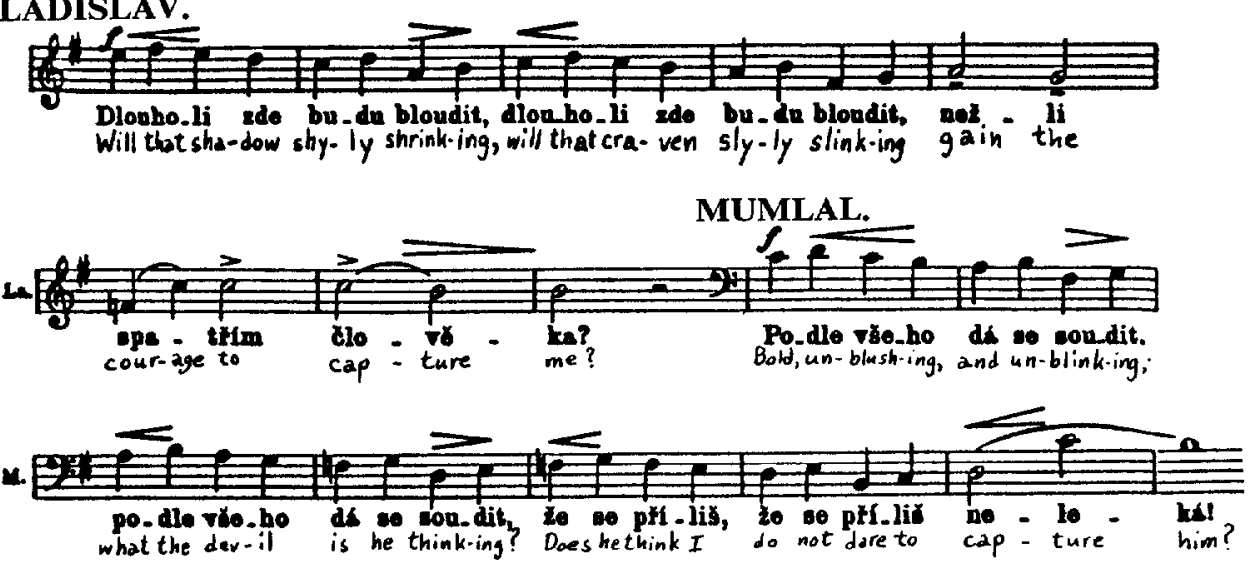

(Two Widows, Act I, \#4, pp. 67-68)

Smetana's "Vivace" shows he was aware of the comic possibilities as, at this point in Züngel's libretto, Ladislav and Mumlal try to keep from stumbling over each other and their words. The alternating $b$ 's and $b l$ 's of the Czech are almost impossible to get out. So, performers have assured us, is our English.

While the instrument for which we write, the human voice, can put its physical workings at our service, those same properties limit us. Vowels and consonants are produced on the sound-stream by altering the size and shape of the oral cavity, and by moving the lips, tongue, and teeth. When sung pitch exceeds the central octave of a singer's vocal range (usually the octave down from middle $\mathrm{C}$ for males and the octave up from middle $\mathrm{C}$ for females), the size and shape of the oral cavity influence pitch production, 
thus limiting what vowels and consonants can be produced. High pitches require that the soft palate be raised. The higher the pitch, the higher the soft palate. The best vowels for high notes are i, a, I, and (those of fee, father, but, and bit), because the back of the tongue is down during their pronunciation. For low notes, the front of the jaw drops. The best vowels are $o$ and $\rho$ (those of boat and bought). What voiced consonants are sung where depends on how they are produced - hard $g$ and American $r$ can be sung quite low ; $l$, if produced with the tongue tip touching the center of the hard palate can be sung quite high. Unvoiced consonants for extreme pitches should be chosen for how well they shape the oral cavity for the following vowel and pitch.

A passage from $L a$ Traviata illustrates an extremely difficult problem in translating for high pitches :

\section{VIOLETTA}

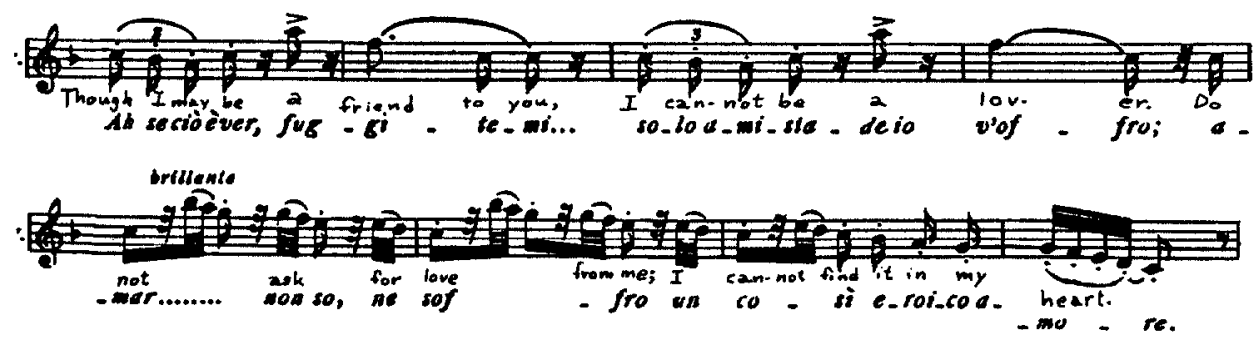

(Act I, pp. 63-64)

Here Verdi sets high notes on such cruel consonants and vowels that most sopranos scant their pronunciation, not out of laziness, but out of sheer physical inability. We did not feel these difficulties were intrinsic to Verdi's intentions, so we set the easier a and a vowels above the staff.

While coloratura runs may go very high or low, the translator should choose, not the best vowel for the high or low spot, but the one which will sound best overall. For instance, while $i$ is easy to sing high, spread over a long run it resembles a fire siren. Usually a, open and full-bodied, is preferred for runs. Besides, singers can easily edge it towards $ə$ on top and towards $\supset$ down low. On the other hand, dramatic purpose may override concerns of vocal beauty. We followed Mozart in setting a run which sinks to low E on I :
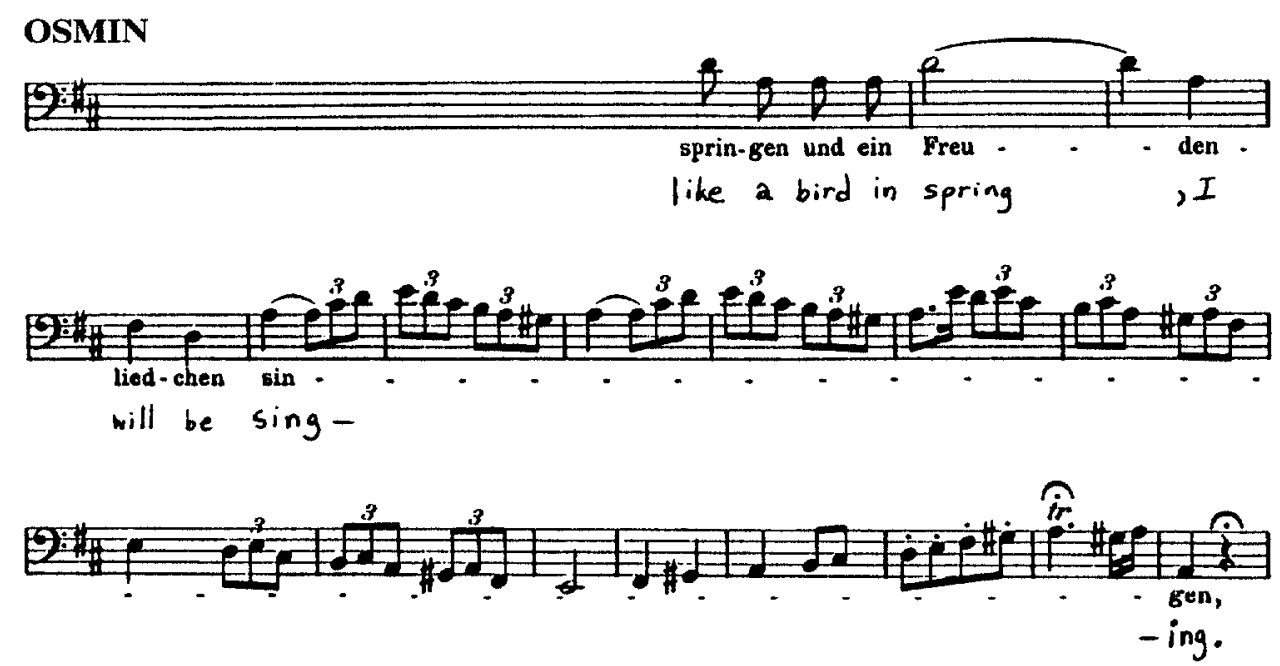

(Abduction, Act III, \#19, meas. 151-68, p. 151) 
Evidently, Mozart did not have beauteous vowels in mind for his five-hundred pound bass canary.

Last, we come to the translator's most difficult problem, matching foreign rhythms. In language, rhythm is made up of stress and burden. Burden refers to the time it takes to say a syllable in normal speech. The longer a syllable takes to say, the longer or heavier its burden is said to be. While music sometimes deforms language rhythms, it often follows them. A translator dealing with a rhythm highly different from that of his own language may have trouble finding a natural-sounding line. Each foreign language presents the translator with a different set of difficulties.

In sung French, by convention, many extremely light syllables are pronounced which are not enunciated in spoken French. "Vive la médecine!" four syllables when spoken, when sung rates seven "Vi-ve la mé-de-ci-ne! "In Gounod/Barbier and Carré's Le médecin malgré lui, these words are set in a very un-English pattern :

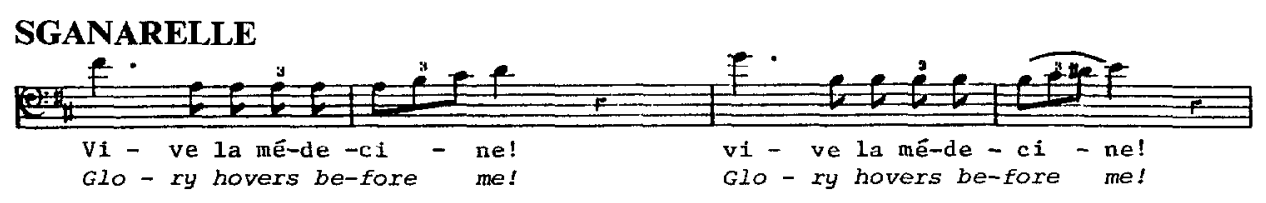

(Act III, \#10, p. 159)

Our stage director, looking at our rough libretto, asked, "Couldn't you come up with a stronger word than "hover' ?" "Look at the music," we replied. We needed a highburden first syllable and three light ones in a row. Probably any stronger word would have a stronger burden, and would be mispronounced when sung : "beckons," say (Glory beckons me on and on), becomes "bickens."

While we rarely have as much trouble with overall German rhythm as with French, German, too, has a frequent light final $e$. In both French and German, when the light $e$ is in line-ending position, the music is least likely to disguise the difference in burden : most English unaccented final syllables are heavier than their French or German counterparts. Poor translators often solve the problem with final -ing, frequently distorting word order or using an unnatural progressive aspect to get it - and -ing's burden is too heavy besides. We try to comb English for its rare, but existent, light final syllables. Useful are

a) short-voweled personal pronouns in unaccented position :

What do toil and sweat avail us

when both flesh and spirit fail us ?

(Abu Hassan, \# 1, p. 7.)

OMAR : Take my heart!

OMAR : Know my mind!

FATIMA : You do me credit.

(Abu Hassan, \#6, p. 55.)

FATIMA : I haven't read it. 
Husbands too may cry "Alack,"

when the prick of horns afflict 'em.

Men may laugh and wives attack -

of such cares I am no victim :

all my love is sherry sack!

(Le médecin, Act I, \#3, pp. 45-46.)

b) the -es plural ending for nouns and third-person present singular ending for verbs :

This fact be true the world around :

'tis not a man's purse that bewitches.

What if his purse be empty found,

so long as he fill his britches.

(Le médecin, Act II, \#7, pp. 97-98.)

c) the verb, noun, and adjective suffix -le:

MARTINE :

Hark at him, learnèd man, aquoting Aristotle!

SGANARELLE :

'Tis a fact I am learned, and you an empty noddle!

(Le médecin, Act I, \#1, p. 15.)

FRONTIN :

If you were offered silk and sable,

would you cleave to your love for Frontin ?...

MARTON :

Were I to dine at the master's table,

who should be my partner if not my Frontin?

(Ma tante Aurore, II.iii, \#8, pp. 152-153.)

d) the noun, verb, and adjective suffix -er :

I desire revenge much stronger,

that will be remembered longer!

(Le médecin, Act I, \#2, p. 33.)

What are you hiding?

Is there some treachery undercover?

If I discover you have a lover,

I will unleash my ax and hack him limb from limb !

(Abu Hassan, \#7, pp. 69-70.)

and a host of odd words like "bosom" and "hyena," which can be pressed into service on occasion. (By the way, those quotations from our version of Le médecin malgré lui sound odd because we translated that opera into seventeenth-century English. But that is another story.)

Czech has presented us with the trickiest burdens. All Czech words are accented on their first syllables, except in prepositional phrases, where the preposition becomes, as it were, the first syllable and receives the stress. Furthermore, Czech is a predominantly multi-syllabic language. As a result, in Czech, for both single words and phrases, the stress pattern / $\times 1 \times$ (strong weak weak weak) is common. This pattern is very uncommon in English.

When Smetana set $/ \mathrm{x} \times \mathrm{x}$ on $\frac{2}{4}$ d\&bb or $\frac{4}{4} d d d d$, we were able to find English phrases fairly easily, because in music the third note of each of those patterns gets a sec- 
ondary stress. Phrases like "See my sister" and "Not to worry" abound in English. However, when Smetana set the / $x \times x$ pattern as J\&d it became difficult to find a word with a burden small enough to fit on the third sisteenth note. The following excerpt illustrates approach :

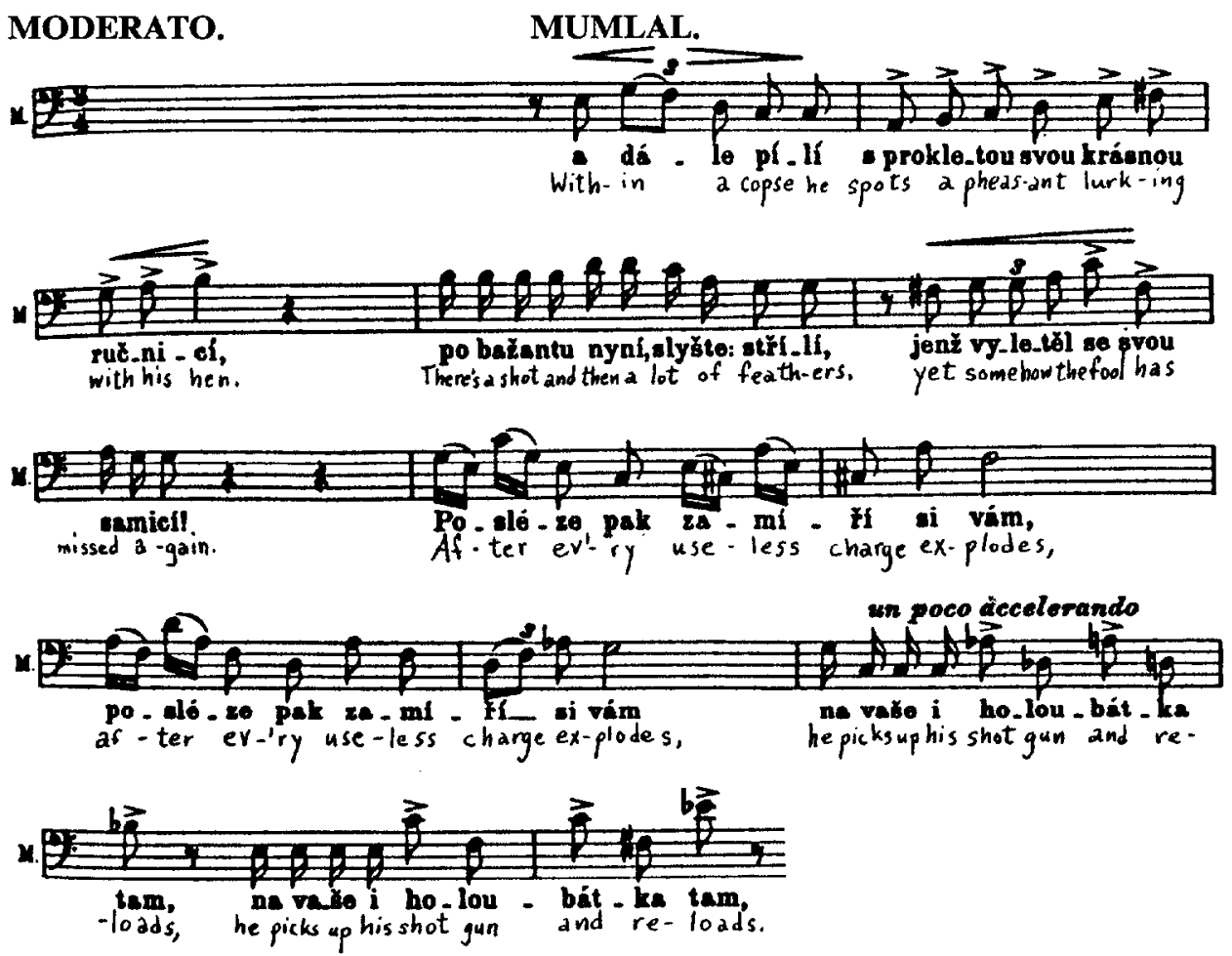

(Two Widows, Act I, pp. 54-55)

"There's a shot and then a lot of feathers" is in the psps" pattern. "Shot" and "lot" would normally both require musical stresses. However, they have unusually low burdens for English stressed syllables; each consists of a short vowel between single consonants. (Words like "blast" and "group" take much longer to pronounce.) Consequently, they can be packed into a line sung $/ \mathrm{x} \mathrm{x} \mathrm{x} / \mathrm{x} \times \mathrm{x} / \mathrm{x}$. Similarly, while "he picks up his shotgun" is usually spoken $x / x x / x$, we've made it $/ x \times x / x$, by having Mumlal stress "he," as if to say, "this idiot." While "picks" ends in two consonants, its $s$ elides to "up." And so we trudged through Two Widows, searching for low-burden English nouns and verbs.

After all these examples, it should be clear that an opera translator needs knowledge of music, of vocal technique, of prosody, and of rhyme - plus some knowledge of foreign languages. Although outside the scope of this paper, knowledge of playwriting and stagecraft also helps. Since opera translation is poorly paid, few people deliberately acquire this combination of skills. We hope both situations will change. It is desperately important that good opera translation drive out bad - not only so that the masterpieces of the past regain their dramatic immediacy, that match of note to thought which the composers intended - but also for the sake of contemporary opera. What 
models have English librettists? Poor translations. Let us offer the lyric muse good translations. She may reward us by inspiring good new librettists.

\section{WORKS CITED}

BOIELDIEU, François Adrien, composer, Ma tante Aurore [My Aunt Aurore]. Librettist Charles de Longchamps. Trans. Mark Herman and Ronnie Apter, 1981.

GOUNOD, Charles François, composer, Le médecin malgré lui (The Doctor in Spite of Himself). Librettists Paul Jules Barbier and Michel Carré. Based on the farce by J.B.P. Molière. Trans. Mark Herman and Ronnie Apter, 1979.

MOZART, Wolfgang Amadeus, composer, Die Entfiuhrung aus dem Serail (The Abduction from the Seraglio). Librettist Gottlieb Stephanie, Jr. Trans. Mark Herman and Ronnie Apter, 1979.

MOZART, Wolfgang Amadeus, composer, Die Zauberföte [The Magic Flute]. Librettist Emanuel Johann Schikaneder. Trans. Mark Herman and Ronnie Apter, 1982.

SMETANA, Bedrich, composer, Dvě ydovy [Two Widows]. Librettist Emanuel Züngel. Trans. Mark Herman and Ronnie Apter, 1984.

VERDI, Giuseppe, composer, Un giorno di regno [A Day in the Reign]. Librettist Felice Romani. Trans. Mark Herman and Ronnie Apter, 1983.

VERDI, Giuseppe, composer, La Traviata. Librettist Francesco Maria Piave. Based on La dame aux camélias by Alexandre Dumas fils. Trans. Mark Herman and Ronnie Apter, 1981.

WAGNER, Richard, composer and librettist, Das Rheingold [The Rhinegold]. Trans. Mark Herman and Ronnie Apter, 1983.

WEBER, Carl Maria von, composer, Abu Hassan. Librettist Franz Karl Hiemer. Based on a tale in The Thousand and One Nights. Trans. Mark Herman and Ronnie Apter, 1980.

All the above works cited are published by and are available from Mark Herman and Ronnie Apter, 13 Woodside Road, Madison, New Jersey 07940, The United States of America. All translations in the above works cited and in this article are copyright (c) Mark Herman and Ronnie Apter. Except for brief phrases quoted in reviews, none may be cited or reproduced without permission. 